\title{
Influence of cantilever position and implant connection in a zirconia custom implant-supported fixed partial prosthesis: in silico analysis
}

\author{
Influência da posição do cantilever e da conexão do implante em um modelo de zirconia de uma prótese \\ parcial fixa implanto-suportada: análise in sílico
}

\author{
Juliana Maria Coutinho BASTOS ${ }^{a}$, Dimorvan BORDIN ${ }^{b}$, Andréa Araújo de VASCONCELLOS ${ }^{c *}$, \\ Milton Edson MIRANDA a
}

\begin{abstract}
asão Leopoldo Mandic, Faculdade de Odontologia e Centro de Pesquisas Odontológicas, Campinas, SP, Brasil 'UNICAMP - Universidade Estadual de Campinas, Faculdade de Odontologia de Piracicaba, Piracicaba, SP, Brasil 'UDF - Centro Universitário do Distrito Federal, Brasília, DF, Brasil
\end{abstract}

\begin{abstract}
Resumo
Introdução: Uma melhor distribuição de tensão em implantes e mini-pilares em próteses parciais fixas implanto-suportadas é essencial na reabilitação em região posterior de mandíbula. Objetivo: Avaliar a influência da posição do cantilever e conexão do implante em uma prótese fixa de três elementos confeccionada totalmente em zircônia através do método de elementos finitos tridimensionais (MEF). Material e método: Foram confeccionados quatro modelos baseados em cortes tomográficos da região posterior da mandíbula com uma prótese parcial parafusada fixada em três fixações personalizadas de zircônia. Os fatores investigados do estudo in sílico foram: posição do cantilever (mesial ou distal) e conexão do implante (hexágono externo ou cone morse). Uma carga de $100 \mathrm{~N}$ para a região de pré-molares e de $300 \mathrm{~N}$ para a região de molares foi usada para simular a força oclusal em cada modelo para avaliação da distribuição de tensões nos implantes, mini pilares, parafusos e tecido ósseo cortical e medular. Resultado: A conexão hexágono externo apresentou maior concentração de tensão no osso cortical quando comparado ao cone morse. Para ambas conexões, o cantilever distal aumentou a tensão no osso cortical. O pico máximo de tensão foi localizado no osso cervical em contato com as primeiras roscas internas do primeiro implante. Os parafusos protéticos e dos mini-pilares associados ao cantilever distal apresentaram maior concentração de tensão, especialmente na conexão hexágono externo. Conclusão: Conexão do implante cone morse associada ao cantilever mesial apresentou uma opção de tratamento mais favorável para a reabilitação na região posterior de mandíbula.
\end{abstract}

Descritores: Projeto do implante dentário-pivô; análise de elementos finitos; zircônio.

\begin{abstract}
Introduction: A better tension distribution on implants and abutments in implant-supported fixed partial prosthesis is essential in the rehabilitation of posterior mandible area. Objective: To evaluate the influence of cantilever position and implant connection in a zircônia custom implant-supported fixed partial prosthesis using the 3-D finite element method. Material and method: Four models were made based on tomographic slices of the posterior mandible with a zirconia custom three-fixed screw-retained partial prosthesis. The investigated factors of the in silico study were: cantilever position (mesial or distal) and implant connection (external hexagon or morse taper). $100 \mathrm{~N}$ vertical load to premolar and $300 \mathrm{~N}$ to molar were used to simulate the occlusal force in each model to evaluate the distribution of stresses in implants, abutments, screws and cortical and cancellous bone. Result: The external hexagon (EH) connection showed higher cortical compression stress when compared to the morse taper (MT). For both connections, the molar cantilever position had the highest cortical compression. The maximum stress peak concentration was located at the cervical bone in contact with the threads of the first implant. The prosthetic and abutment screws associated with the molar cantilevers showed the highest stress concentration, especially with the EH connection. Conclusion: Morse taper implant connetions associated with a mesial cantilever showed a more favorable treatment option for posterior mandible rehabilitation.
\end{abstract}

Descriptors: Dental implant-abutment design; finite element analysis; zirconia. 


\section{INTRODUCTION}

An implant-supported cantilevered fixed partial prosthesis is a good treatment option in clinical conditions in which the use of implants is limited due to anatomical, physiological or economic factors and represents an alternative to removable partial dentures'. However, this modality has a biomechanical challenge and should be carefully evaluated, considering that the presence of a cantilever increases the concentration of stress on implants, prosthetic abutments, screws, and the bone-implant interface, especially when a distal cantilever is used ${ }^{2}$.

Biomechanical analyses have determined that the types of implant-connections have different behaviors ${ }^{3}$. In external hexagon models, axial preload of the abutment screw is the determining factor for the stability of the connection, with the possibility of abutment rotation. On the other hand, a morse taper implant has more stability considering its better biological seal, mechanical strength, and greater resistance to movement ${ }^{3}$.

Regarding the integrity of the bone-implant interface, compressive forces favour the interface, while tensile stresses lead to break it. When a cantilever prosthesis is planned in a biomechanically unfavorable region, a stress overload may occur, resulting in bone resorption, screw loosening or fracture, or fracture of the prosthesis framework ${ }^{4}$. The abutment/implant interface is one of the most important region in which the mechanical behaviour should be evaluated, considering that both vertical and oblique forces affect this region ${ }^{5}$.

In this context, this current study evaluated the influence of cantilever position (mesial or distal) and implant connection (external hexagon or morse taper) in a zirconia custom implantsupported fixed partial prosthesis in the posterior mandible, by examining the distribution of stresses in implants, abutments, screws and cortical and cancellous bone using the 3-D finite element method. The hypothesis was that the stress distribution in implant-supported fixed partial prosthesis is influenced by the cantilever position and implants connection.

\section{MATERIAL AND METHOD}

\section{Model Construction}

A representative mandibular bone model was constructed based on an STL file microtomography from a database (Solidworks $2013^{\circledR}$ Solidworks Corporation ${ }^{\circledR}$, Waltham, Massachusetts, EUA). An external hexagon dental implant (EH) $(4.1 \times 9 \mathrm{~mm})$ and a morse taper dental implant (MT) $(4.0 \times 9 \mathrm{~mm})$, both with trapezoidal shape threads, were modeled based on commercially available products. The EH was virtually positioned at the same level as the cortical bone while the MT was positioned $1 \mathrm{~mm}$ below the cortical bone. Their respective abutments and abutment screws were positioned. A three-fixed screw-retained partial prosthesis was constructed based on an STL file microtomography from a database. Two prosthetic sets were constructed according to the cantilver position: Molar (M) or pre-molar (PM). Thus, four groups were obtained: G1: MT-pm (morse taper implants and cantilever at pre-molar position); G2: MT-m (morse taper implants and cantilever at molar position); G3: EH-pm (external hexagon implants and cantilever at pre-molar position). G4: EH-m (external hexagon implants and cantilever at molar position). The set was exported to the Ansys Workbench software (Ansys W-orkbench 14.0 ${ }^{\circledast}$, Swanson Analysis Inc., Houston, PA, EUA) to perform the mathematical analysis.

A tetrahedral quadratic $0.60 \mathrm{~mm}$ element-size mesh was generated after a convergence analysis at 5\%. The Young modulii and Poison ratios of the materials were set as: Titanium (110,000 Mpa, 0.35); Cortical bone (13,700 Mpa, 0.30); Cancellous bone (1,370 Mpa, $0.30)$; and Zirconia (205,000 Mpa; 0.22$)^{6}$. All models were considered as homogeneous, isotropic and linearly elastic. The model was completed fixed at both lateral faces of cortical and cancellous bone to represent the mandible. A force of $300 \mathrm{~N}$ was vertically applied to the molars, while a $100 \mathrm{~N}$-load was applied to the premolars ${ }^{7}$. Data was evaluated according to the minimum principal stress (compression stress) for bone and maximum von Mises stress for prosthetic components and implants.

\section{RESULT}

The compression and von Mises stresses (MPa) were evaluated. The cortical bone presented higher stress concentration when compared to cancellous bone, regardless of the implant connection or cantilever position.

The MT connections (G1 and G2) demonstrated lower cortical compression stress when compared to the $\mathrm{EH}$ connections (G3 and G4). The molar cantilever position had the highest cortical compression stress for both connections. The maximum stress peak concentration was located at the cervical bone in contact with the threads of the first implant.

At the cancellous bone level, both molar cantilever positions (G2 and G4) presented higher stress concentrations when compared to the pre-molar cantilevers. The MT-m (G2) had the highest cancellous bone stress (Figure 1).

Regarding the prosthetic components, both MT implants (G1 and G2) showed higher von Mises stress when compared to the EH implants. The peak stress concentration was located at the internal implant surface in contact with the abument walls (Figure 2).

A similar stress behavior concentration was observed for the abutment; MT-m showed the highest stress (359.38 MPa) with the peak stress concentration located at the abutment's collar in contact with the implant wall, followed by EH-m (248.08 MPa) with the peak stress located at the collar surface (Figure 3).

The EH abutment screw associated with a molar cantilever showed the highest stress concentration, especially in the molar region $(98.59 \mathrm{MPa})$. The peak stress was located at the first threads. The EH-m implant-crown interface showed the highest stress concentration (100.86 MPa) (Figure 4). 


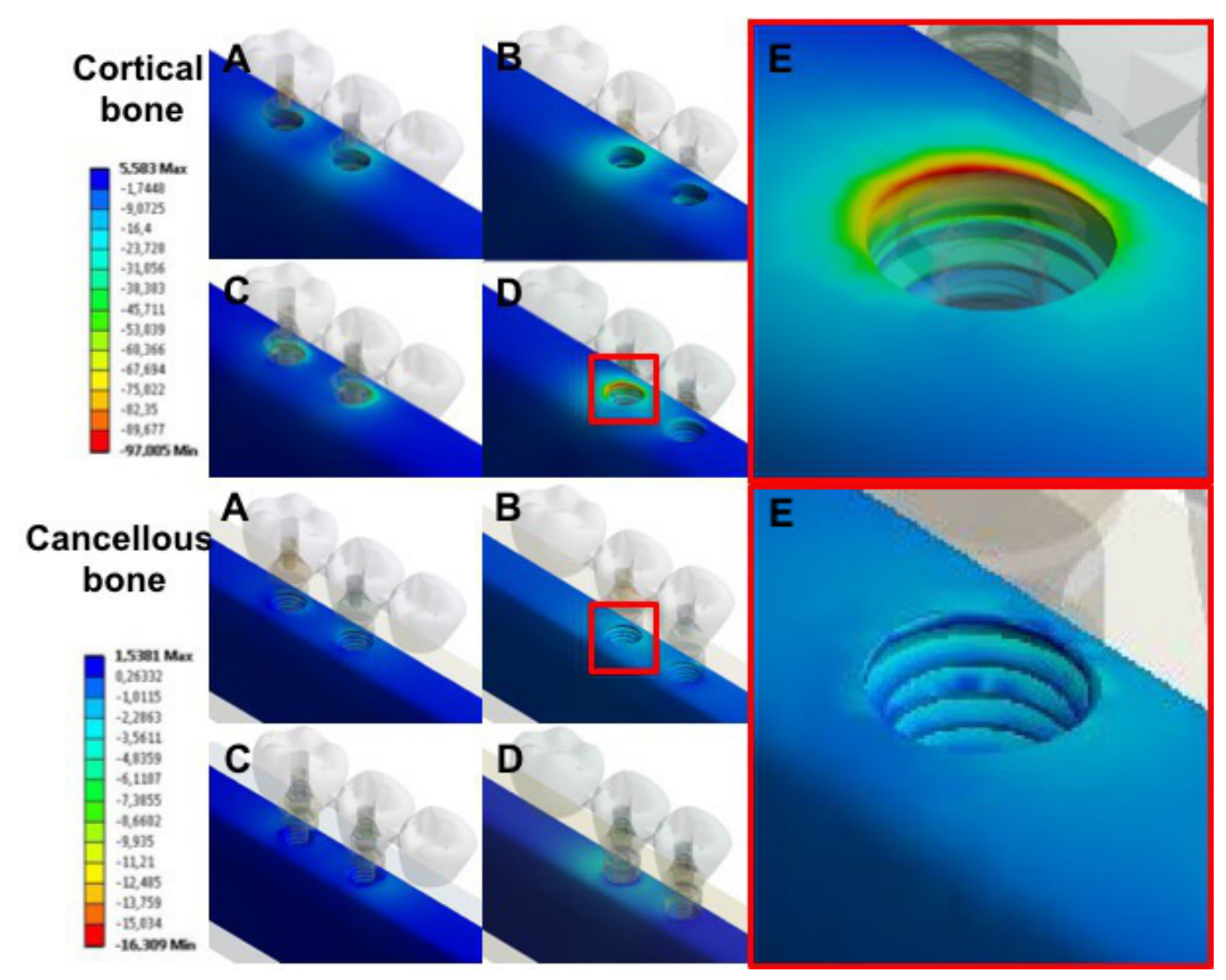

Figure 1. Qualitative analysis of the minimum principal stress for bone (compression stress = negative values). Cortical bone: A. MT-pm; B. MT-m; C. EH-pm; D. G4: EH-m; E. Highlight of the stress peak concentration at the first implant threads on EH-m. Cancellous bone: A. MT-pm; B. MT-m; C. EH-pm; D. EH-m; E. Highlight of the stress concentration on MT-m.

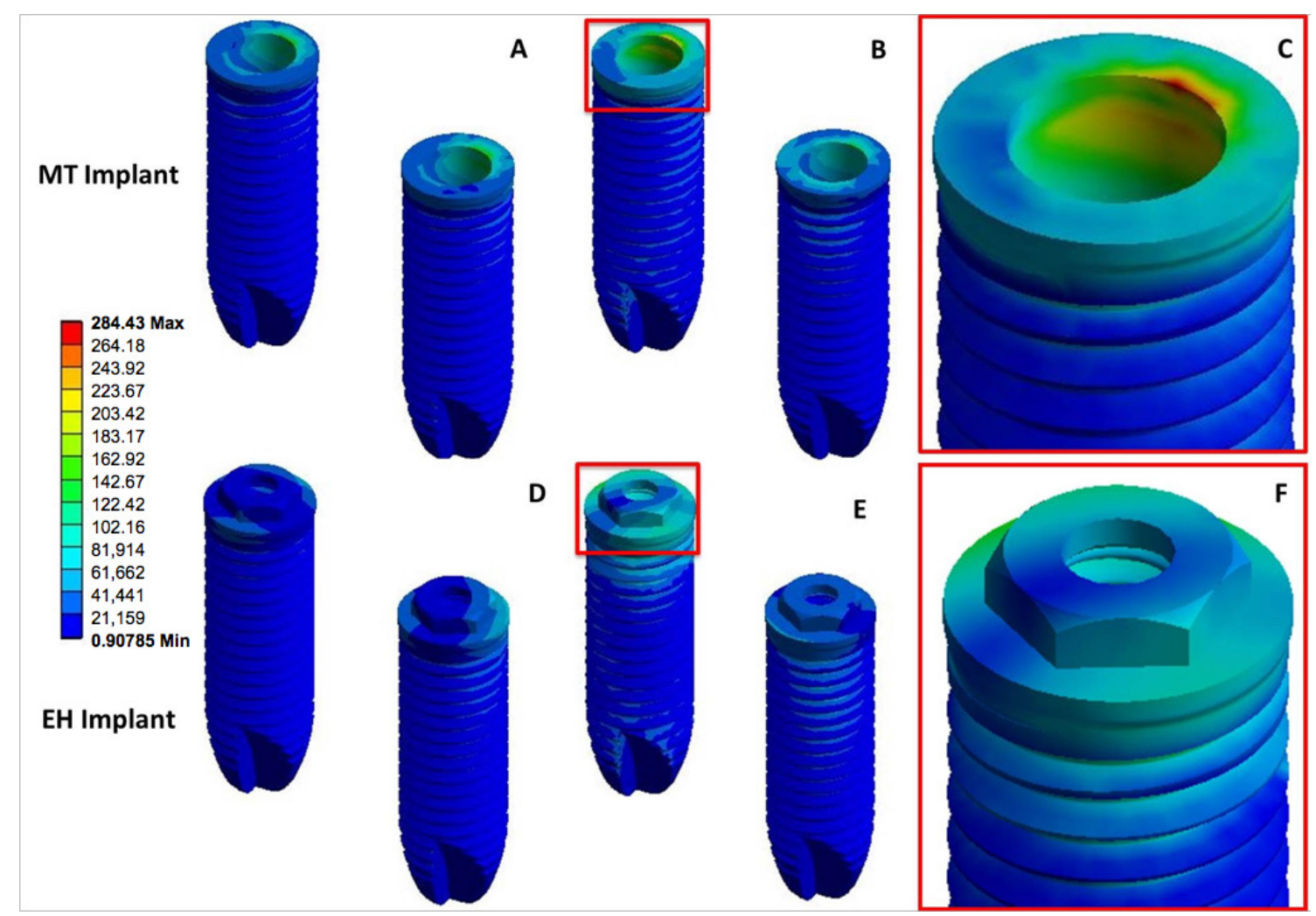

Figure 2. Isometric view of the implants showing the sites with the highest stress concentration. A. MT-m; B. MT-pm; C. Highlight of the stress concentration at the internal implant surface of MT-m; D. EH-m; E. EH-pm; F. EH stress peak concentration. 

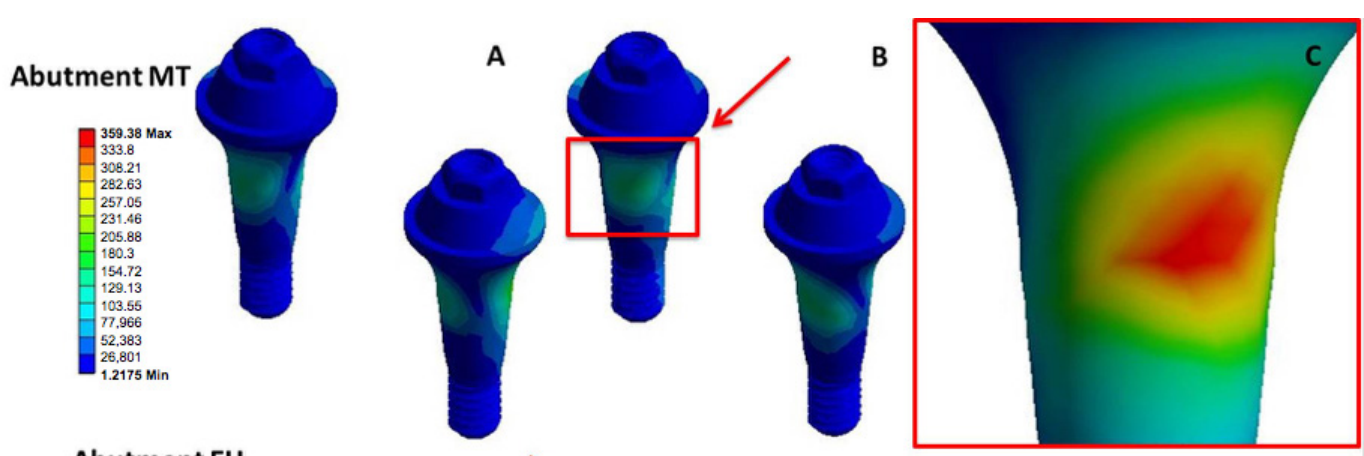

Abutment EH
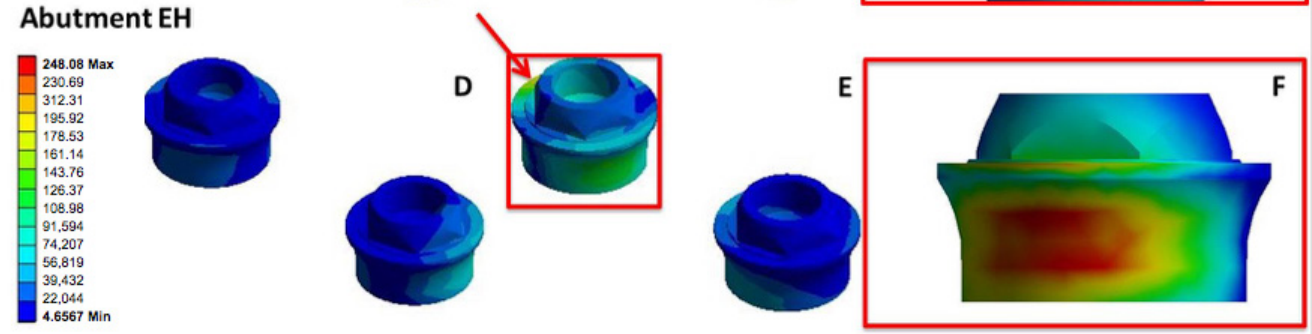

\section{Abutment screw EH}
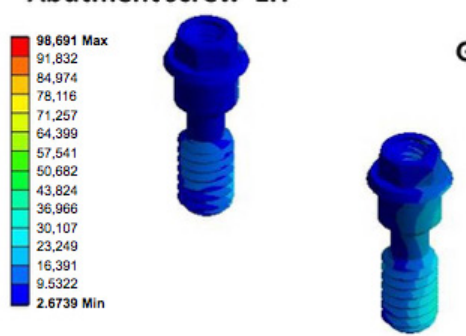

G
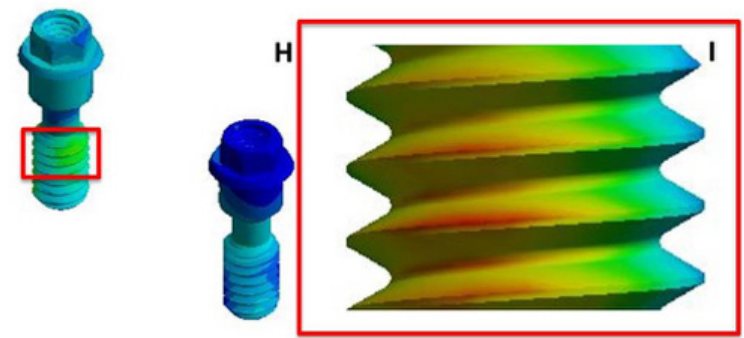

Figure 3. Qualitative analysis of the stress distribution for abutments. Abutment MT: A. MT-m; B. MT-pm; C. MT abutment collar area in contact with implant wall. Abutment EH: D. EH-m; E. EH-pm; F. EH collar surface. Abutment screw EH: G. distal cantilever; H. mesial cantilever; I. Highlight of the stress concentration on distal cantilever.

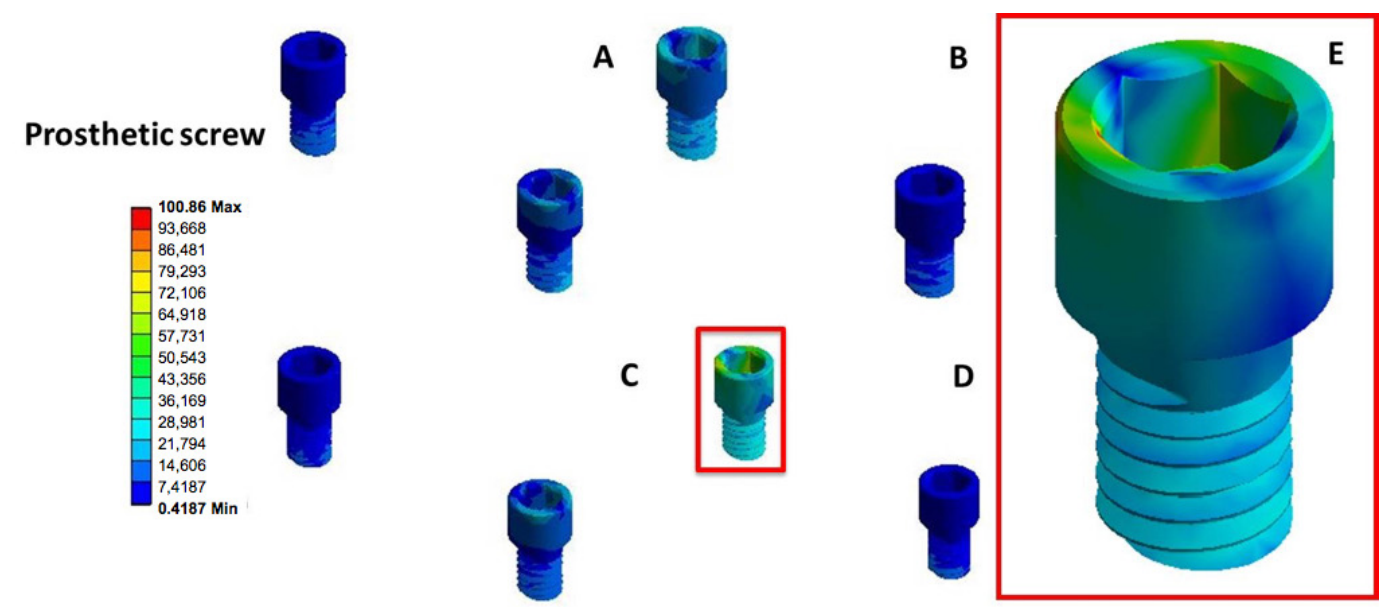

Figure 4. Distribution of stress concentration on prosthesis screws. A. MT-m; B. MT-pm; C. EH-m; D. EH-pm; E. Peak stress concentration on HE distal cantilever.

\section{DISCUSSION}

The hypothesis of this study was confirmed, considering that the stress distribution in a fixed implant-supported prosthesis was influenced by the cantilever position and implant connection.

The stress patterns on implants were higher around the implant adjacent to the cantilever in all models. It was noted that the presence of a cantilever in implant-supported fixed partial prosthesis promoted an increase of tension directly around the marginal bone of the implants ${ }^{2}$, especially around the implant adjacent to the cantilever ${ }^{8}$.

On the other hand, Hälg et al. ${ }^{9}$ did not observe diferences between bone resorption of the implant adjacent to the cantilever when considering the implant distant from the cantilever. Those authors affirmed that the position or extension of the cantilever did not influence the success of rehabilitation or bone resorption, but it should be considered that the extension of the cantilever 
did not exceed one element. Our study showed different results, in which the implant adjacent to the cantilever in all models had higher stress patterns; in addition, when the distal cantilever was analysed, it presented a greater stress pattern for the implants, abutments, screws and bone tissue, concluding that the cantilever position influenced the stress distribution.

When implants are placed, the masticatory force is absorbed by the bone, differently from natural teeth due to the presence of the periodontal ligament ${ }^{10}$. The cantilever extension increases the force that is transferred to implants, mini-abutments, screws, and the bone-dental implant interface ${ }^{11}$. Romanos et al. ${ }^{12}$ affirmed that prosthetic screw loosening is the most commom complication with dental implants. Our study showed that mini-abutment screws and dental prostheses adjacent to a cantilever in all models had higher tension values, mainly for the external hexagon implant-connetion with a distal cantilever.

It has been suggested that cantilevers must be used in specific clinical condicions in which the force transferred to the prosthesis is minimized, such as anterior restorations, with patients with no parafunctional activity, and favorable bone density sites (i.e. mandible) ${ }^{13}$. However, the use of a cantilever is an good alternative in bone defect sites, avoiding the need for bone grafting prior to the placement of a dental implant; while also being effective when anatomical structures cause concern for placing dental implants, such as the maxillary sinus or mental foramen ${ }^{1}$. In the present study, the distal cantilevers showed higher tension in relation to the mesial cantilevers, regardless of the type of connection (external hexagon or morse taper implant).

An important fator to discuss is that the external hexagon and morse taper implants have different mechnical principles ${ }^{14}$. In the external hexagon configuration, the axial preload of the abutment screw is a determining factor for stability of the connection. In the presence of a horizontal load, there is no lock form or positive locking by the external hexagon. Additionally, the external hexagon determines the rotational position ${ }^{15}$. Alternatively, the morse taper connection has gained wide popularity for being more resistant to fatigue and for promoting a better seal against bacterial infiltration when considering conventional connections ${ }^{16}$, with sealing and friction principles. The morse taper has a design in which a cone with an angulation between 2 and 4 degrees is embedded in another cone by friction, without the need for screws, creating a cold weld between the parts, promoting greater resistance to displacement by axial and lateral forces and higher resistance to rotational movements ${ }^{17}$. Our results revealed a better tension distribution on implants and abutments with a morse-taper connection when compared with external hexagon connections, in accordance with the studies discussed.

The external hexagon was the first implant connection proposed for the rehabilitation of complete edentulous patients, and has advantages such as greater number of prosthetic options and more professionals with mastery of the technique. The clinical use may be for multiple or single prostheses, and havw a lower cost. However, this connection has disadvantages, such as higher rates of mechanical complications (i.e. loosening or fracture of prosthetic or abutment screws), and higher potential of marginal bone resorption ${ }^{3,7}$. In the present study, the abutments and prosthetic screws adjacent to the cantilever showed higher tension. In addition, higher stress was found in cortical alveolar bone when a distal cantilever was used with an external hexagon connection. Our results showed that the external hexagon dental implants presented the maximum stress peak concentration at the cervical bone in contact with the first implant threads. In this aspect, Maeda et al. ${ }^{17}$ reported that there is a higher concentration of stresses in the cervical region of the external hexagon dental implant, inducing separation of the components. The morse taper dental implant had lower stress concentration, which was located at its base and first internal threads, in accordance with Goiato et al. ${ }^{14}$, both of which emphasized that the configuration of the external hexagon and the morse taper implants employ different biomechanical principles.

The advantages of the morse taper implant are greater mechanical stability and resistance to rotational movements ${ }^{18}$, more uniform stress distribution on the abutment, and better distribution of these forces to the bone tissue. Furthermore, the stress reduction on the screw results in possibility reduced liklihood of screw loosening, allows for gap reduction, provides less probability of bacterial invasion and mechanical problems, and presents a low potential for bone resorption with preservation of peri-implant health ${ }^{19,20}$. These characteristics result in better stress distribution with the implants and abutments of the morse taper implant observed in our study.

Zanatta et al. ${ }^{21}$ affirmed that the morse taper dental implants should be positioned 1-2 mm below the cortex of the bone, according to the manufacturers recommendations, to provide better dissipation of the masticatory loads. Having masticatory loads beginning in the cancellous bone, which has a lower modulus of elasticity than cortical bone, resulted in less stress on bone and greater presevation of this area. In our study, the implants were located $1 \mathrm{~mm}$ below the cortical bone, resulting in higher stress concentration in cancellous bone when a morse taper dental implant with a distal cantilever were used.

The application of repeated loads can lead to fatigue failure of the interface, decreasing peri-implant bone density, and leading to the formation of bone defects ${ }^{22}$. Regarding the stress distribution in bone and implant, the stress peak concentration was located at the screw, cortical bone and implant neck area on implant/abutment interface, both for the vertical and oblique forces ${ }^{23}$. This study confirms our results, in which higher stress peak concentration was located at the cortical bone, screw and implant neck area on models with an external hexagon dental implant.

From a biomechanical point of view, the abutment screw is the most fragile point of the implant/prosthesis complex, considering that there is higher stress concentration on the superior area of implant ${ }^{24}$. In simulations of clinical masticatory, the stress peak concentration was found on implant neck area and cortical bone, although these values were lower when splinted implant prostheses were evaluated ${ }^{23}$. These statements corroborate with the results of the present study, in which the highest stresses were located on the neck of abutment and the screws of the external hexagon dental implants. 
The Finite Element Method applied to biomechanics has emerged as an extremely useful tool to numerically calculate mechanical aspects of stress and compression, and to evaluate the biomechanical behavior of human biomaterials and tissues, considering the difficulty of performing an in vitro evaluation ${ }^{25}$. Our study was performed to simulate clinical situations, to analyse the stress distribution on bone, implant and prosthesis components; and to critically evaluate biomechanics in a quantitative and qualitative way, taking into account the variation in properties and individual anatomy. However, our study was limited to evaluate cantilever implant prostheses in the posterior region of the jaw. Therefore, more studies should be performed to evaluate different bone densities (maxila) and other load parameters (direction and intensity).

\section{CONCLUSION}

It can be concluded that the morse taper implant-connetion with a mesial cantilever showed a more favorable treatment option for posterior mandible rehabilitation.

\section{ACKNOWLEDGEMENTS}

The authors thank the São Leopoldo Mandic School of Dentistry and Piracicaba Dental School, State University of Campinas (UNICAMP) for providing the necessary equipment to the development this research.

\section{REFERENCES}

1. Greenstein G, Cavallaro J Jr. Cantilevers extending from unilateral implant-supported fixed prostheses: a review of the literature and presentation of practical guidelines. J Am Dent Assoc. 2010 Oct;141(10):1221-30. http://dx.doi.org/10.14219/jada.archive.2010.0049. PMid:20884924.

2. Gonda T, Yasuda D, Ikebe K, Maeda Y. Biomechanical factors associated with mandibular cantilevers: analysis with three-dimensional finite element models. Int J Oral Maxillofac Implants. 2014 Nov-Dec;29(6):e275-82. http://dx.doi.org/10.11607/jomi.3663. PMid:25397809.

3. Borie E, Orsi IA, de Araujo CP. The influence of the connection, length and diameter of an implant on bone biomechanics. Acta Odontol Scand. 2015 Jul;73(5):321-9. http://dx.doi.org/10.3109/00016357.2014.961957. PMid:25598357.

4. Sanivarapu S, Moogla S, Kuntcham RS, Kolaparthy LK. Implant fractures: rare but not exceptional. J Indian Soc Periodontol. 2016 JanFeb;20(1):6-11. http://dx.doi.org/10.4103/0972-124X.154190. PMid:27041830.

5. Kitamura E, Stegaroiu R, Nomura S, Miyakawa O. Biomechanical aspects of marginal bone resorption around osseointegrated implants: considerations based on a three-dimensional finite element analysis. Clin Oral Implants Res. 2004 Aug;15(4):401-12. http://dx.doi. org/10.1111/j.1600-0501.2004.01022.x. PMid:15248874.

6. Abreu E, Aritonovska E, Reichenbach P, Cristofari G, Culp B, Terns RM, et al. TIN2-tethered TPP1 recruits human telomerase to telomeres in vivo. Mol Cell Biol. 2010 Jun;30(12):2971-82. http://dx.doi.org/10.1128/MCB.00240-10. PMid:20404094.

7. Isidor F. Influence of forces on peri-implant bone. Clin Oral Implants Res. 2006 Oct;17(S2 Suppl 2):8-18. http://dx.doi.org/10.1111/j.16000501.2006.01360.x. PMid:16968378.

8. Greco GD, Jansen WC, Landre J Jr, Seraidarian PI. Stress analysis on the free-end distal extension of an implant-supported mandibular complete denture. Braz Oral Res. 2009 Apr-Jun;23(2):182-9. http://dx.doi.org/10.1590/S1806-83242009000200014. PMid:19684954.

9. Hälg GA, Schmid J, Hämmerle CH. Bone level changes at implants supporting crowns or fixed partial dentures with or without cantilevers. Clin Oral Implants Res. 2008 Oct;19(10):983-90. http://dx.doi.org/10.1111/j.1600-0501.2008.01556.x. PMid:18828813.

10. Michalakis KX, Calvani P, Hirayama H. Biomechanical considerations on tooth-implant supported fixed partial dentures. J Dent Biomech. 2012;3(0):1-16. http://dx.doi.org/10.1177/1758736012462025. PMid:23255882.

11. Gupta S, Gupta H, Tandan A. Technical complications of implant-causes and management: a comprehensive review. Natl J Maxillofac Surg. 2015 Jan-Jun;6(1):3-8. http://dx.doi.org/10.4103/0975-5950.168233. PMid:26668445.

12. Romanos GE, Gupta B, Eckert SE. Distal cantilevers and implant dentistry. Int J Oral Maxillofac Implants. 2012 Sep-Oct;27(5):1131-6. PMid:23057026.

13. Chen Y-Y, Kuan C-L, Wang Y-B. Implant occlusion: biomechanical considerations for implant-supported prostheses. J Dent Sci. 2008 Jun;3(2):65-74

14. Goiato MC, Pellizzer EP, Silva EV, Bonatto LR, Santos DM. Is the internal connection more efficient than external connection in mechanical, biological, and esthetical point of views? A systematic review. Oral Maxillofac Surg. 2015 Sep;19(3):229-42. http://dx.doi.org/10.1007/s10006015-0494-5. PMid:25910993.

15. Krishnan V, Tony Thomas C, Sabu I. Management of Abutment screw loosening: review of literature and report of a case. J Indian Prosthodont Soc. 2014 Sep;14(3):208-14. http://dx.doi.org/10.1007/s13191-013-0330-2. PMid:25183903.

16. Peruzetto WM, Martinez EF, Peruzzo DC, Joly JC, Napimoga MH. Microbiological seal of two types of tapered implant connections. Braz Dent J. 2016 May-Jun;27(3):273-7. http://dx.doi.org/10.1590/0103-6440201600604. PMid:27224559.

17. Maeda Y, Satoh T, Sogo M. In vitro differences of stress concentrations for internal and external hex implant-abutment connections: a short communication. J Oral Rehabil. 2006 Jan;33(1):75-8. http://dx.doi.org/10.1111/j.1365-2842.2006.01545.x. PMid:16409521.

18. Feitosa PC, Lima AP, Silva-Concílio LR, Brandt WC, Neves AC. Stability of external and internal implant connections after a fatigue test. Eur J Dent. 2013 Jul;7(3):267-71. http://dx.doi.org/10.4103/1305-7456.115407. PMid:24926204. 
19. Gehrke S, Delgado-Ruiz R, Frutos J, Prados-Privado M, Dedavid B, Marín J, et al. Misfit of three different implant abutment connections before and after cyclic load application: an in vitro study. Int J Oral Maxillofac Implants. 2017 Jul/Aug;32(4):822-9. http://dx.doi.org/10.11607/ jomi.5629. PMid:28708914.

20. Mangano C, Mangano F, Shibli JA, Ricci M, Sammons RL, Figliuzzi M. Morse taper connection implants supporting "planned" maxillary and mandibular bar-retained overdentures: a 5-year prospective multicenter study. Clin Oral Implants Res. 2011 Oct;22(10):1117-24. http:// dx.doi.org/10.1111/j.1600-0501.2010.02079.x. PMid:21251077.

21. Zanatta LC, Dib LL, Gehrke SA. Photoelastic stress analysis surrounding different implant designs under simulated static loading. J Craniofac Surg. 2014 May;25(3):1068-71. http://dx.doi.org/10.1097/SCS.0000000000000829. PMid:24777027.

22. Carter DR, Caler WE, Spengler DM, Frankel VH. Fatigue behavior of adult cortical bone: the influence of mean strain and strain range. Acta Orthop Scand. 1981 Oct;52(5):481-90. http://dx.doi.org/10.3109/17453678108992136. PMid:7331784.

23. Bal BT, Caglar A, Aydin C, Yilmaz H, Bankoglu M, Eser A. Finite element analysis of stress distribution with splinted and nonsplinted maxillary anterior fixed prostheses supported by zirconia or titanium implants. Int J Oral Maxillofac Implants. 2013 Jan-Feb;28(1):e27-38. http://dx.doi.org/10.11607/jomi.2442. PMid:23377079.

24. Djebbar N, Serier B, Bouiadjra BB, Benbarek S, Drai A. Analysis of the effect of load direction on the stress distribution in dental implant. Mater Des. 2010 Apr;31(4):2097-101. http://dx.doi.org/10.1016/j.matdes.2009.10.042.

25. Wakabayashi N, Ona M, Suzuki T, Igarashi Y. Nonlinear finite element analyses: advances and challenges in dental applications. J Dent. 2008 Jul;36(7):463-71. http://dx.doi.org/10.1016/j.jdent.2008.03.010. PMid:18455859.

\section{CONFLICTS OF INTERESTS}

The authors declare no conflicts of interest.

\section{${ }^{*}$ CORRESPONDING AUTHOR}

Andréa Araújo de Vasconcellos, UDF - Centro Universitário do Distrito Federal, 70390-045 Brasília - DF, Brasil, e-mail: andrea. odonto@yahoo.com.br

Received: July 5, 2018

Accepted: July 24, 2018 